\title{
The Know Nothing Movement in Iowa: Editor's Introduction
}

\section{MARVIN BERGMAN}

THIS ISSUE OF THE ANNALS OF IOWA is devoted to the Know Nothing movement in Iowa. Nationally, the movement had phenomenal early success as a secret organization expressing hostility toward immigrants and Roman Catholics. That success led the Know Nothings to seek to extend their influence into the political arena in the mid-1850s, a time when party realignments had created a political vacuum. Although the new Republican party quickly preempted the Know Nothings' success, Know Nothings played a key role in the realignment of party politics in the United States and in Iowa. Despite their importance, Iowa's Know Nothings have until now remained, as Robert Dykstra's title has it, the Know Nothings nobody knows.

This issue as a whole reveals the building blocks of history as an interpretive process, and illustrates that putting those blocks together into a single structure requires serendipity as well as hard work. About two years ago, Michael Hill, a researcher for the North Carolina Division of Archives and History, called me to report that he had just found, in the library's copy of Lamon Hill's Life of Abraham Lincoln (1872), a five-page document, handwritten more than a hundred years ago by William Penn Clarke, a prominent early Iowa politician. Hill wondered if I would be interested in publishing the document in the Annals of Iowa. I was interested, of course, particularly since I was corresponding with several scholars who were at work on various topics in Iowa's antebellum political history. This document, it seemed, would

THE ANNALS OF IOWA 53 (Winter 1994). (CThe State Historical Society of Iowa, 1994. 
complement some of those other potential articles. One of those, Robert Cook's overview of the political culture of antebellum Iowa, appeared in the Summer 1993 issue of the Annals. That article provides a valuable introduction-and historiographical guidance-for readers of the articles in this issue.

As I corresponded with these scholars and read their work and other articles and books, I saw repeated references to a 1965 University of Chicago Ph.D. dissertation by Ronald Matthias, "The Know Nothing Movement in Iowa." Everyone spoke highly of the quality of the dissertation. When I read the microfilm copy of the dissertation in the library of the State Historical Society of Iowa, I, too, was impressed. Why, I wondered, had none of this fine work ever appeared in print, at least to my knowledge? Then I learned that Matthias currently works in Iowa's academic community, no longer as a historian but as an administrator at Wartburg College. When I took the matter up with him, he informed me that, indeed, he never had published anything about Iowa Know Nothings, though he had long ago prepared a conference paper that summarized portions of the dissertation. Eventually, we agreed to publish that unannotated conference paper-with some modest revisions and some equally modest documentation-in this issue.

Among those scholars with whom I had been corresponding about antebellum politics were Tyler Anbinder and Robert R. Dykstra-both of whom had alerted me to Matthias's work. Since 1988, when I had learned of Anbinder's Ph.D. dissertation on the Know Nothing movement, I had been trying to convince him to write about Iowa's Know Nothings. When he proved unable to do so, I asked him if he would provide the setting and annotations for the William Penn Clarke document, and he agreed. Meanwhile, his revised dissertation was published by Oxford University Press last year (see the review in this issue). Robert Dykstra's long-awaited book, Bright Radical Star: Black Freedom and White Supremacy on the Hawkeye Frontier, came out this year. Dykstra returned to Iowa last summer to present a paper at the Congress of Historical Organizations about 
Iowa's Know Nothings. He subsequently agreed to revise it for publication.

Thus was born this special issue of the Annals of Iowa on the Know Nothings in Iowa. The work by Dykstra and Anbinder represents the cutting edge of contemporary scholarship, while Matthias's essay reproduces some of the grounding on which that contemporary scholarship is based. Matthias surveyed a vast range of newspapers and correspondence and visually analyzed election returns. (Because of the provenance of Matthias's essay, thorough documentation proved impossible. Interested readers are urged to return to his dissertation for complete documentation of his sources.) Dykstra's reliance on Matthias's groundbreaking work is evident in the notes to his essay. But since Matthias wrote his dissertation, a generation of scholars has applied new methodological and interpretive techniques to the study of antebellum politics and nativist movements. Dykstra and Anbinder have benefited from the insights that have emerged from that work. Dykstra added his own sophisticated, computer-aided analyses of Iowa election returns, and Anbinder has unparalleled knowledge of the institutional records of Know Nothing organizations throughout the northern states.

For essays that cover the same rather narrow topic, there is remarkably little overlap, because each has a different goal. Dykstra's article provides a summary of the electoral rise and fall of the Iowa Know Nothings, along with an analysis of the sources of their support. Matthias offers a broader look at the cultural basis of the movement, along with some impressionistic suggestions about the narrower motivations of the politicians who were drawn to the movement. Anbinder's introduction to William Penn Clarke's commentary on the national meetings of Know Nothings and Republicans in 1856 places that prominent Iowa Know Nothing's actions in the national political context. ${ }^{1}$

1. For anyone whose research interest in the movement is kindled by these essays, William Penn Clarke's papers, held by the State Historical Society of Iowa, would be a good place to start. 
Careful readers will note that, because the three authors draw on somewhat different sources for somewhat different purposes, they do not always agree about the nature of the Know Nothing movement. For example, scholarship in the intervening years since Matthias completed his work has suggested that nativist sentiment may have been more prevalent in Iowa than the sources Matthias used indicate, but he has chosen to stand by his judgments based on his reading of the evidence. These articles offer valuable perspectives on the long-overlooked Know Nothing movement in Iowa, but it is unlikely that the last word has been written on the topic. At least, the authors and I hope not. 
Copyright of Annals of Iowa is the property of State of Iowa, by \& through the State Historical Society of Iowa and its content may not be copied or emailed to multiple sites or posted to a listserv without the copyright holder's express written permission. However, users may print, download, or email articles for individual use. 